Article

\title{
Characteristics of Smart Sustainable City Development: Implications for Project Management
}

\author{
R. P. J. Ron Schipper ${ }^{1, *}$ and A. J. Gilbert Silvius ${ }^{2,3}$ \\ 1 Van Aetsveld, Maanlander 47, 3824 MN Amersfoort, The Netherlands \\ 2 Project and Programme Management, LOI University of Applied Sciences, Leidsedreef 2, \\ 2352 BA Leiderdorp, The Netherlands; mail@gilbertsilvius.nl \\ 3 Faculty of Engineering \& the Built Environment, University of Johannesburg, Johannesburg, \\ 2006 Gauteng, South Africa \\ * Correspondence: rpj.schipper@gmail.com
}

Received: 25 May 2018; Accepted: 15 September 2018; Published: 26 September 2018

\begin{abstract}
Projects and project management (PM) are becoming a way of working, and many changes in society have evolved because of projects. However, will the societal agenda also influence the project management discipline? Societal issues generated by urban population growth and rapid urbanization arise in cities. Making a city "smart" and sustainable is emerging as a strategy to mitigate these issues. How does this development impact project management? In order to answer this question, we performed meaningful learning by mapping the concepts for Smart Sustainable Cities (SSC) and project management and developing prior and post concept maps. We identified four major findings describing the implication of societal issues on project management: quality of life acts as a societal objective for PM; PM governs autonomous projects with new business models; and PM success criteria are related to stakeholders and long-term effects, as well as extensive connection to the digital world with consideration of the privacy and ethics. From this, we were able to redefine the definition of project management as "a collaborative endeavor of all affected stakeholders equivalently participating in exploring and exploiting, via an autonomous temporary organization, fit-for-purpose deliverables with connections to the digital platform, thereby aiming to prepare the entities of the affected stakeholders for the future". Our study is novel and relevant for PM and SSC practice: societal issues are on the strategy agenda of many governments and companies, and these will drive the projects that are performed in this environment. The project management community should align with this development, since these challenges are part of their environment. As a start, a comprehensive understanding of the impact of societal issues is relevant to build new definitions, competences, and supporting processes.
\end{abstract}

Keywords: smart cities; smart sustainable cities; project management; sustainable development

\section{Introduction}

Projects and project management (PM) are becoming a way of working, and many changes in society have evolved because of projects. Several authors and professional institutions coin this development the "projectification" of society [1]. However, does the "projectification of society" also imply that project management takes the societal agenda into consideration? Social relevancy is an important condition in order to become a true profession [2]. So, does the "projectification of society" also imply the "societalization of project management"?

The question is: which developments cover significant societal issues and transformations that have the potential to impact the field of projects and project management? It is evident that our overwhelming consumption and waste patterns, destructive use of scarce resources, climate problems 
due to abundant emissions, pollution, and social issues are important societal issues. From the recognition that humans are solely responsible for this, a sustainable development approach has emerged to balance the economic, social, and environmental aspects. This approach aims to provide current and future generations with their basic needs for a good quality of life. Sustainability is now both on the public and corporate agenda. While sustainable development is a process of change [3], the relationship between sustainability and project management has been an emerging research strand for several years now [4], and its implications are already slowly entering the project management standards such as the Individual Competence Baseline [5].

However, sustainable development is a rather generic concept that is contextually-driven and perceived as difficult to be made explicit. This might be one of the reasons preventing a more fast transition to an integrated project management approach. Differentiating from a generic approach to integrate sustainable development concepts (e.g., [6]), we are eliciting explicit societal issues at the place where these are most prominent and globally relevant: cities. After all, the improved quality of life and economic perspectives urge many people to migrate to cities worldwide. As a consequence, most resources are consumed in cities, implying their "economic importance on the one hand, and but poor environmental and social performance on the other hand" [7]. It questions the current and future livability for the majority of people on earth. Due to their importance, cities must play an important role in the regional, national, and global sustainable development [7]. Making a city "smart" (and sustainable) is emerging as a strategy to mitigate the problems generated by the urban population growth and rapid urbanization [8].

The development of a (smart sustainable) city is "a complex multidimensional process through which changes are applied at all city levels; aiming to enhance the sustainability of a city and provide a high quality of life for its citizens through the use of ICTs and other means" [9]. Projects and project management create changes [10], deal with complexity, and are challenging unique endeavors [11]. Therefore, we can assume Smart Sustainable City (SSC) development to be characterized and perceived as project(s). As discussed by [4], adopting a societal perspective to project management changes the perspective on project management. In line with this reasoning, our hypothesis is that SSC and their development can be at the origin of the societalization of project management.

In order to further explore our hypothesis, we have formulated four research questions:

1. What are the defining characteristics of a Smart Sustainable City (SSC)?

2. What are the defining concepts of project management?

3. How do these SSC characteristics influence the management of projects to develop Smart Sustainable Cities?

4. How can the development of an SSC enhance our understanding of project management?

This paper is structured as follows. Section 2 presents background information on all parts of the SSC and the concepts of project management. After that, the research methodology is explained in Section 3. Section 4 shows the findings of our research and we finalize this paper with a discussion in Section 5 answering our final research question and presenting a new definition on project management.

\section{Smart Sustainable Cities and Their Development}

A "city" is a place that is larger or more important than a town where people live and work [7]. Cities grew from mercantile settlements based on craft and trade into industrialized environments with a grown population to staff factories. Although productive, these cities also were highly polluted, disease-ridden, and unhealthy. In the late 1800s, various social and cultural programs attacked these problems, and gradually the "sanitary" city emerged providing infrastructures and services such as clean water, sanitation, public education, recreational facilities, and green space along with establishment of public and non-governmental institutions [12]. 
The improved quality of life and economic perspectives make many people move to cities. In 2014, $54 \%$ of all people lived in urban areas, and this is predicted to rise to $66 \%$ in 2050 [13,14]. However, almost $70 \%$ of global greenhouse gases are emitted in urban areas [15]. This highlights the contradiction between high economic and poor environmental performance on the other hand. This questions the current and future livability of cities regarding traffic, pollution, city crowding, poverty [16], and climate issues affecting access to water, coastal flooding, food supply, and hurricanes [17]. Therefore, cities must play an important role in regional, national, and global sustainable development [7].

\subsection{Smart Sustainable Cities}

The term Smart Sustainable Cities (SSC) connects the smart city and sustainable cities concept. It is a new phenomenon that became widespread during the mid-2010s $[7,9,18]$. The concept emerged from five different developments, namely: sustainable cities, smart cities, urban ICT, sustainable urban development, sustainability and environmental issues, and urbanization and urban growth [18]. The individual concepts of the smart city, sustainable city, and smart sustainable city are all described and discussed in various publications.

The origin of the concept of Smart Cities can be traced back to at least the Smart Growth Movement of the late 1990s or even the 1960s [18], but emerged more seriously from 2010. Although the term "smart city" is broadening its conceptualization, it was initially fueled by the application of technology in an urban situation. A city can be considered a system of systems consisting of various interconnected objects $[8,19]$. Smartifying the system is about the pervasion of sensor technologies to gather data and identify objects, communication capabilities to connect and distribute data and information processing systems, and computational analytics to improve urban functions and save resources to improve environmental performance [20,21]. Therefore, digitization places a new digital layer between the city infrastructure and city services layer conceptualization.

After studying the academic and empirical literature, the authors of [16] summarized the smart city objectives into four categories: environmental sustainability, life quality and well-being, knowledge and intellectual capital, and participation. It can be said that the objectives can be identified from both the urban challenges and from the opportunity for cities to be attractive to citizens and businesses [22].

Many definitions of smart cities exist [18,22,23]; however, these lack consensus. Table 1 summarizes several definitions of smart cities, including the oft-cited one by [24], which expresses a broad interpretation of the Smart City concept. The authors of [24] stated that "we believe a city to be smart when investments in human and social capital and traditional (transport) and modern (ICT) communication infrastructure fuel sustainable economic growth and a high quality of life, with a wise management of natural resources, through participatory governance".

Table 1. Definition of smart city.

\begin{tabular}{lc}
\hline \multicolumn{1}{c}{ Definition } & Reference \\
\hline $\begin{array}{l}\text { Key conceptual components of a Smart City are three core factors: technology (infrastructures } \\
\text { of hardware and software), people (creativity, diversity, and education), and institution } \\
\text { (governance and policy). Given the connection between the factors, a city is smart when }\end{array}$ & [25] \\
investments in human/social capital and information technology (IT) infrastructure fuel & \\
sustainable growth and enhance a quality of life through participatory governance. & [26] \\
\hline $\begin{array}{l}\text { A city well-performing in a forward-looking way in economy, people, governance, mobility, } \\
\text { environment, and living, built on the smart combination of endowments and activities of }\end{array}$ & [24] \\
self-decisive, independent, and aware citizens & \\
\hline $\begin{array}{l}\text { A city is smart when investments in human and social capital and traditional (transport) and } \\
\text { modern information and communication technology (ICT) infrastructure fuel sustainable }\end{array}$ & \\
economic growth and a high quality of life, with a wise management of natural resources, \\
through participatory governance.
\end{tabular}


Table 1. Cont.

\section{Definition}

Reference

A Smart City is based on intelligent exchanges of information that flow between its many different subsystems. This flow of information is analyzed and translated into citizen and commercial services. The city will act on this information flow to make its wider ecosystem more resource-efficient and sustainable. The information exchange is based on a smart governance operating framework that is designed to make cities sustainable.

A Smart City [refers to] a local entity-a district, city, region or small country-that takes a holistic approach to employ[ing] information technologies with real-time analysis that encourages sustainable economic development.

The application of information and communications technology (ICT) with their effects on human capital/education, social and relational capital, and environmental issues is often indicated by the notion of a Smart City.

The aspect of sustainability remains limited in many Smart City definitions [18]. We define sustainable development along with the Brundland definition as "meeting the needs of the present without compromising the ability of future generations to meet their own needs" [3]. This concept applied to city development led to the development of various sustainable city models reflecting different dimensions of sustainability such as "zero-carbon eco-city" and "ubiquitous eco-city" [28]. However, these city models are limited if judged according to whether they meet the goals of all three pillars of sustainability, making them far removed from the true concept of a sustainable city, especially from economic and social viewpoints [30]. In addition to the three defined pillars of sustainable development, culture is emerging as a fourth pillar. Culture is argued to be relevant to urban planning and will bring "thoughtfulness and openness, and contributes to a world with complementary, pluralized visions of development" [31]. It is more and more recognized by city policy-makers as an important element.

Based on the sustainability approach, this fourth pillar should be part of Smart City development, and therefore, it is important to integrate sustainability and smart city frameworks so that both views are accounted for. Therefore, the more accurate term "Smart Sustainable Cities" (SSC) should be used [32]. Table 2 presents an overview of definitions mentioned in the literature. We follow [20], who denote a SSC as a city that is "supported by a pervasive presence and massive use of advanced ICT, which, in connection with various urban domains and systems and how these intricately interrelate, enables cities to become more sustainable and to provide citizens with a better quality of life" [20].

Based on all of the constituent definitions, we find that there is agreement on the significant role of ICT in smart urban development [22], that the meaning of a Smart (Sustainable) City is multi-faceted [23], and has a holistic point of perception [32] where people and environment play an important role.

Table 2. Definition of a Smart Sustainable City (SSC).

\section{Definition}

Reference

A Smart Sustainable City is one in which the seams and structures of the various urban systems are made clear, simple, responsive, and even malleable via contemporary technology and design. Citizens are not only engaged and informed in the relationship between their activities, their neighborhoods, and the wider urban ecosystems, but are actively encouraged to see the city itself as something they can collectively tune, such that it is efficient, interactive, engaging, adaptive, and flexible, as opposed to the inflexible, monofunctional, and monolithic structures of many 20th century cities.

"A smart and sustainable city invests in human and social capital, manages resources wisely, has citizens who participate in city governance, and has a traditional and modern infrastructure that supports economic growth to create a high quality of life for its inhabitants". 
Table 2. Cont

\begin{tabular}{|c|c|}
\hline Definition & Reference \\
\hline $\begin{array}{l}\text { Cities that use ICT technologies to be more intelligent and efficient in the use of resources, } \\
\text { resulting in cost and energy savings; improved service delivery and quality of life; and a } \\
\text { reduced environmental footprint. }\end{array}$ & [35] \\
\hline $\begin{array}{l}\text { The Smart Sustainable City seeks to achieve concern for the global environment and lifestyle } \\
\text { safety and convenience through the coordination of infrastructure. Smart Sustainable Cities are } \\
\text { realized through the coordination of infrastructures consist of two infrastructure layers that } \\
\text { support consumers' lifestyles together with the urban management infrastructure that links } \\
\text { these together using IT. }\end{array}$ & [36] \\
\hline $\begin{array}{l}\text { A city that strategically utilizes many smart factors such as information and communication } \\
\text { technology to increase the city's sustainable growth and strengthen city functions, while } \\
\text { guaranteeing citizens' happiness and wellness. }\end{array}$ & [37] \\
\hline $\begin{array}{l}\text { To expose the feasibility of rapidly progressing toward our energy and climate objectives at } \\
\text { a local level while proving to citizens that their quality of life and local economies can be } \\
\text { improved through investments in energy efficiency and the reduction of carbon emissions }\end{array}$ & [15] \\
\hline $\begin{array}{l}\text { Must provide ICT-based solutions to address public issues as well as to improve } \\
\text { competitiveness to ensure a more sustainable future of the city. }\end{array}$ & [38] \\
\hline $\begin{array}{l}\text { A SSC must deliver a sustainable, prosperous, and inclusive future for its citizens through an } \\
\text { effective integration of its digital, physical, and human systems }\end{array}$ & [39] \\
\hline $\begin{array}{l}\text { A smart sustainable city is an innovative city that uses ICTs and other means to improve the } \\
\text { quality of life, efficiency of urban operation and services, and competitiveness, while ensuring } \\
\text { that it meets the needs of present and future generations with respect to economic, social, } \\
\text { and environmental aspects. }\end{array}$ & [40] \\
\hline $\begin{array}{l}\text { A city that meets the needs of its present inhabitants, without compromising the ability for other } \\
\text { people or future generations to meet their needs, and thus does not exceed local or planetary } \\
\text { environmental limitations, and where this is supported by ICT. }\end{array}$ & [18] \\
\hline
\end{tabular}

Various publications have tried to further unravel the Smart City and Smart Sustainable City concepts by describing their dimensions or components. Table 3 summarizes several characterizations from academic, industrial, and governmental publications.

Table 3. Dimension of smart cities.

\begin{tabular}{clc}
\hline City Mode & \multicolumn{1}{c}{ Components } & Reference \\
\hline smart city & technology, community and people & {$[19]$} \\
\hline smart city & people, infrastructure and operations & {$[41]$} \\
\hline smart city & social, management, economic, legal, technology, and sustainability & {$[42]$} \\
\hline smart city & $\begin{array}{l}\text { management and organization, technology, governance, policy context, people and } \\
\text { communities, economy, built infrastructure, and natural environment }\end{array}$ & {$[8]$} \\
\hline smart city & land, technology, citizens and government & {$[16]$} \\
\hline smart city & $\begin{array}{l}\text { government, mobility, services, community, economy, natural environment, } \\
\text { and built environment }\end{array}$ & {$[22]$} \\
\hline smart city & $\begin{array}{l}\text { a smart economy, smart mobility, a smart environment, smart people, } \\
\text { smart (human) living, and, finally, smart governance. }\end{array}$ & {$[26]$} \\
\hline smart & economy, governance, environment, society; technology, and infrastructure & {$[40]$} \\
\hline
\end{tabular}

Frequently cited is the characterization of smart cities published by The Centre of Regional Science at the Vienna University of Technology [22], which identifies a dimensioning of the smart city into six axes: smart economy; smart mobility; smart environment; smart people; smart (human) living; and, finally, smart governance [24]. 
The defining characteristics of a Smart Sustainable City are less developed. We follow the description provided by the [43]. This paper defined five pillars or (sub)concepts for the Smart Sustainable City, in which we see certain similarities with the smart city dimensioning:

1. Economy-The city must be able to thrive: jobs, growth, finance. Related terms are: Employment, Gross domestic product (GDP), Market-Global/Local, Viability, Investment, Public-private partnership (PPP), Value chain, Risk, Productivity, Innovation, Compensation

2. Governance-The city must be robust in its ability for administrating policies and pulling together the different elements. Terms: Regulatory, Compliance, Processes, Structure, Authority, Transparency, Communication, Dialogue, Policies, Standards, Citizen services

3. Environment-The city must be sustainable in its functioning for future generations. Terms: Sustainable, Renewable, Land use, Biodiversity, Water/Air, Waste, Workplace

4. Society-The city is for its inhabitants (the citizens). Terms: People, Culture, Social networks, Tech Savvy, Demographics, Quality of life, User experiences, Equal access, End consumers, Community needs, The city as a database

5. Technology and infrastructure: The following physical and service infrastructures are commonly found in the literature as key aspects for a Smart Sustainable City: Smart energy, Smart buildings, Smart transportation, Smart water, Smart waste, Smart physical safety and security, Smart health care, Smart education. These infrastructures are traditional and very physical in nature. The convergence with digital (ICT) infrastructures leads them to become "smart".

Reflecting on the above, we make several observations. First, the lack of consensus leads to the situation where the SSC concept is used to identify multiple solutions and city programs with unclear goals. Also, different terminology is used to declare the same projects $([8,16,22])$. Further, the authors of [44] conclude that most definitions are not specific enough to guide implementation.

The development of a Smart Sustainable City is a complex process of change [9], but it is relevant for the sustainable development of society [7]. The authors of [45] relate sustainable development to the concepts of projects and project management. In the next section, we explore the concepts of project management.

\subsection{Project Management}

Although project management (PM) is supposed to originate from ancient Egyptian times, we can see the first development of PM as a discipline in the 1950s [46]. Back then, projects were primarily seen as reflecting a rational and predictable view on the world. The spreading of PM to almost all of the industries and the rise of new social views on organizing and interactions (e.g., [47]) made the discipline of PM evolve from a "hard perspective" into seeing PM as an "instrument to manage (organizational) change" [10], "converting vision into reality" [48] with "quantitative and qualitative objectives" [49]. This development enriched the field of PM with topics and research strands such as e.g., behavioral aspects, leadership, and complexity. The attention for sustainability in business (and cities) also led to the research strand on integrating sustainability into the veins of projects and PM [4]. The history and recent development has led to various definitions of PM, as shown in Table 4 .

Below we highlight the main definitions of PM. We built on [50], who described the nature of PM as a production function, a temporary organization, agency for change, agency for resource utilization, and an agency for uncertainty. Based on definitions and recent insights, we derive the following concepts. 
Table 4. Definitions of project management.

\begin{tabular}{|c|c|c|}
\hline Nr. & Definition & Reference \\
\hline 1. & $\begin{array}{l}\text { Project management is to use an ensemble of tools and techniques to direct the } \\
\text { usage of different resources to accomplish a unique, complex, and one-time task } \\
\text { within the constraints of time, cost, and quality. Each task requires a particular mix } \\
\text { of the tools and techniques that are structured to fit the task environment and life } \\
\text { cycle (from conception to completion) of the task. }\end{array}$ & [11] \\
\hline 2. & $\begin{array}{l}\text { "A project is a whole of actions limited in time and space, inserted in, and in } \\
\text { interaction with a politico-socio-economic environment, aimed at and tended } \\
\text { toward a goal that is progressively redefined by the dialectic between the thought } \\
\text { (the project plan) and the reality". }\end{array}$ & [51] \\
\hline 3. & $\begin{array}{l}\text { Planning, controlling, and monitoring all of the attributes involved in a project and } \\
\text { directed them to accomplish the goals of a project within a given time along with } \\
\text { satisfying the cost, quality, and performance. }\end{array}$ & [52] \\
\hline 4. & $\begin{array}{l}\text { The process of controlling the achievement of project objectives. Utilizing the } \\
\text { existing organizational structures and resources, it seeks to manage the project by } \\
\text { applying a collection of tools and techniques, without adversely disturbing the } \\
\text { routine operation of the company. }\end{array}$ & [53] \\
\hline 5. & Project management is a science and art of converting vision into reality. & {$[48]$} \\
\hline 6. & $\begin{array}{l}\text { The application of knowledge, skills, tools, and techniques to project activities to } \\
\text { meet project requirements; it further describes it as an organizational approach to } \\
\text { the management of an ongoing operation. }\end{array}$ & [54] \\
\hline 7. & $\begin{array}{l}\text { A series of activities embodied in a process of getting things done on a project by } \\
\text { working with project team members and other stakeholders to attain project } \\
\text { schedule, cost, and technical performance objectives. }\end{array}$ & [55] \\
\hline 8. & $\begin{array}{l}\text { An activity regarding the planning, organizing, directing, and controlling of } \\
\text { company resources for a relatively short-term objective that has been established to } \\
\text { complete specific goals and objectives. }\end{array}$ & [56] \\
\hline 9. & $\begin{array}{l}\text { More than just a set of tools, project management is a result-oriented management } \\
\text { style that places a premium on building collaborative relationships among a } \\
\text { diverse cast of characters. }\end{array}$ & [57] \\
\hline 10. & $\begin{array}{l}\text { An endeavor in which human material and financial resources are organized in a } \\
\text { novel way to deliver a unique scope of work of given specification, often within } \\
\text { cost and time constraints, in order to achieve beneficial changes defined by } \\
\text { quantitative and qualitative objectives. }\end{array}$ & [58] \\
\hline 11. & $\begin{array}{l}\text { One can define project management as a temporary endeavor to create a unique } \\
\text { product, service, or result, a cumulus of interrelated activities that are driven by a } \\
\text { main goal, always considering the main objective of the organization in question; } \\
\text { in the process, all of the resources that are needed are considered to be used in } \\
\text { order to achieve the goal at its best by consuming less resources for it. }\end{array}$ & [59] \\
\hline 12. & $\begin{array}{l}\text { Planning, organizing, monitoring, and controlling all of the attributes of a project } \\
\text { and directed for the successful accomplishment of a safe project in a given time } \\
\text { satisfying all the cost, quality and performance criteria. }\end{array}$ & [60] \\
\hline 13. & $\begin{array}{l}\text { (Sustainable) project management is the planning, monitoring, and controlling of } \\
\text { project delivery and support processes with consideration of the environmental, } \\
\text { economic, and social aspects of the life cycle of the project's resources, processes, } \\
\text { deliverables, and effects aimed at realizing benefits for stakeholders and } \\
\text { performed in a transparent, fair, and ethical way that includes proactive } \\
\text { stakeholder participation. }\end{array}$ & [6] \\
\hline
\end{tabular}

\subsubsection{Realizing Strategic Change}

The implementation of strategic change has been acknowledged as a business problem for decades, and PM has been put forward as a (partial) solution. This change aspect is mentioned explicitly in the Guide to Project Management Body of Knowledge [58], and is in line with [48] claiming that projects and PM make ideas come true. The prior rational view on PM supposes that the intentions of a limited 
number of stakeholders are steady, and can be easily converted into plans and outcomes, and this plan can be achieved by "the application of knowledge, skills, tools and techniques to project activities to meet project requirements" [11,58]. However, the challenges and opportunities to which a project is an answer are fuzzy, complex and "unique", reflecting the endeavor aspect in the delivery process and the relative low predictability in advance. This is also illustrated by the definition of [51], pointing to the political and emerging perspective of projects: "a project is a whole of actions limited in time and space, inserted in, and in interaction with a politico-socio-economic environment, aimed at and tended toward a goal progressively redefined by the dialectic between the thought (the project plan) and the reality".

The authors of [61] study is one of many studies that show that corporations are not blind for the societal issues that we are faced with, and sustainability is frequently integrated into corporate strategy. We would expect that this also impacts projects and project management. Nevertheless, these societal reflections hardly conquered their place in PM definitions, as shown in Table 3.

\subsubsection{A Temporary Organization Managing Its Stakeholders}

Many definitions mention the temporary aspect of projects [61,62], imposing that a project has a definite start and ending to fulfill its activities and tasks performed by a team, although its results (may) have long-term implications [63]. From a rational perspective, we can see a project as a plan based concept to realize the desired end state, reflecting the intentions and outcomes of its sponsor(s). The latter also identifies, through the agency theory, the relationship between a principal (sponsor) and agent (project) and fosters the emergence of topics such as the role of leadership style, human resources, knowledge management, and project stakeholder management.

Considering the project team as a temporary organization also links projects to a wider context [64], such as the parent organization, while projects operate within a given organizational framework. For understanding and exploiting an effective relation with the project environment (its host organization), the relevance of the institutional theory is argued [64]. Institutions promote social behavior incentives, and its elements make up an organization. Organizations, including temporary organizations, adapt to these internal group requirements and norms as well as the external society [64].

It is clear that projects and their temporary organizations are faced by many other stakeholders, who do not all have the same interest. The PM literature recognizes that project stakeholders are important for project success [63], and the objective of doing stakeholder management is to (continuously) recognize and anticipate opportunities and problems at a time when there is still time and opportunity to maneuvre. This risk-oriented and instrumental "management of stakeholders" approach is focused on making stakeholders do what is needed for project success. However, originally, the concept of stakeholder management emerged due to democratic developments in society to consider "any group or individual who can affect or is affected by the achievement of the firm's objectives" [65]. This refers to a management "for" stakeholders approach in which the project does what is needed for the stakeholders [66-69]). However, the aspect of stakeholder management (in this perception) is given limited attention in current definitions. The closest is the definition by [57], who stated that PM is "more than just a set of tools; but a result-oriented management style that places a premium on building collaborative relationships among a diverse cast of characters".

\subsubsection{Considering All Triple Bottom Line Perspectives}

Although not yet mainstream recognized, the integration of sustainability in projects and PM changes various aspects of PM. The societal and responsibility perspective requires not only considering the project life cycle, but also the life cycle of the deliverables of the project, and the artifacts that this asset makes [70]. Also, the integration will influence the specifications and requirements of the project's deliverable or output, and the criteria for project success [71,72]. However, it also includes the environmental or social aspects in the project's objective and intended output and outcome [2] 
developed together with a broad group of stakeholders [66]. In total, [6] identified 13 areas of project management that will be influenced.

\subsubsection{Dealing with Constraints and Resources}

A project uses resources to fulfill its tasks and deliver its results [53,56,58], which are provided by its stakeholders and sponsors. In PM perspective, (the right) resources are always scarce, and the subsequent issues on the project and organizational level can be understood from population ecology theory [73].

A project is characterized by the presence of constraints that have to be managed, imposing a managerial challenge and additional complexity. The classical iron triangle is, for example, expressed in the British Standards definition on PM: " . . within a given time along with satisfying the cost, quality and performance ... " [74], but also by others (e.g., [11,61]). Simultaneously, the adequate management of constraints also implies the criteria for project success. The authors of [61] mentioned that if (the iron triangle) constraints are met, the management of the project would be deemed successful. However, the criteria for project success have also evolved considerably in line with the development of the concept of projects and PM [75]. The authors of [76] identified 27 different "measures" of project success based on a literature study that resulted in six condensed criteria: (1) "The project is executed in a controlled manner", (2) The agreed project deliverable is completed on schedule and within budget, (3) The project's deliverable is "fit for purpose", (4) The business objectives or goals of the project are realized, (5) The stakeholders of the project are satisfied and, finally, (6) The project prepares the organization for the future. These criteria describe a more integrated and holistic approach to PM.

\subsubsection{Dealing with Uncertainty and Complexity}

We can view the world as a system of systems where a system can comprise stakeholders, objects, and activities. Complexity is there when the system consists of many components with a high degree of interrelatedness; it is called detailed complexity by [77], and can be viewed as a function of information adequacy [78]. An inadequacy of information is caused either by events or causality being unknown (ambiguity), or by an inability to evaluate the effects of actions because too many variables interact [78]. The latter is called dynamic complexity by [77]. Dynamic complexity is related to the concept of ambiguity among stakeholders: the lack of consensus. One of the effects of the dynamic complexity is that decision makers such as project managers and sponsors have to decide under circumstances of "limited understanding and predictability" invoking the possibility of negative effects on the criteria of the iron triangle and negative perceptions due to a perceived lack of control in the future.

To cope with detailed complexity, one needs control, and to cope with dynamic complexity, interaction is necessary. Based on a matrix-confronting dynamic and detail complexity, the authors of [77] defined four strategies to handle complexity: an internal and content-focused approach, an interactive management approach, dynamic management, and systems management.

\subsubsection{Supported by Structured Processes}

A process-oriented view is frequently taken within PM. Guidelines for PM processes such as PMBOK (Project Management Body of Knowledge) [54] and PRINCE2 (Projects in Controlled Environments) standards argue that PM is performed through processes, applying an appropriate set of knowledge in order to implement the project following a plan in a controlled manner [79]. The concept of the project life cycle defines and organizes a project in generic project phases or process groups such as initiating, planning, implementing, controlling, and closing [79].

Although numerous process frameworks, tools, and applications exist, the perceived high failure rate of projects (benchmarked against the iron triangle criteria) suggest that PM comprises more than just processes and knowledge alone [80], as expressed by the other concepts described. It suggests enhancing the perception of project management as a contextual, social, and value-creating perspective [81] supported by structured processes. 
Eventually, building organizational capability, being able to implement projects effectively isn't only of value to these projects and their direct stakeholders. Projects are discovered as the "... way by which organizations fulfill their business plan" [48], and the authors of [82] defined this a new organizational capability adding value to the parent organization.

\section{Method}

In 1972, Novak and Cañas researched how the knowledge of children regarding science changed during their educational career. They based their research on a theory built by [83] that stated that we learn by embedding new concepts and propositions into existing concepts that are already known to the learner. A concept is "a perceived regularity in events or objects, or records of events or objects, designated by a label" [84]. Novak and Cañas represented the knowledge into what they called a concept map. This is "a schematic device for representing a set of concept meanings embedded in a framework of propositions" [85].

Learning or knowledge creation is therefore "meaningful learning accomplished by individuals who have a well-organized knowledge structure in the particular area of knowledge, and also a strong emotional commitment to persist in finding new meanings" [84]. Meaningful learning requires meeting three conditions. Meaningful learning must be a deliberate strategy (opposed to rote learning), the learner must possess prior knowledge, and the knowledge to be learnt must be conceptually clear. Concept maps are supposed to have "high clarity, a clear message, and communicate key ideas" [86].

It is our hypothesis that SSC development will influence our view on project management. In chapter 2, we derived a well-organized knowledge structure of concepts for both SSC and project management, thereby meeting the second and third condition for meaningful learning. From this, we created a preliminary concept map (Figure 1) representing our initial knowledge. As part of our knowledge creation process, we will search for relevant 'cross-links' between different domains of knowledge. We will do this by mapping the concepts of the SSC development on the concepts of project management, and exploring the meaningful relationships by combining interpretations and insights provided by the authors and logical reasoning. Concept maps are usually created in multiple iterations as the understanding of the learner progresses [84]. As the relationship between SSC development and PM is novel, this interpretive approach makes sense.

Initially, our first iteration will identify a characterization of specific SSC development projects. In a second iteration, we will generalize this to our revised understanding of the concepts of project management.

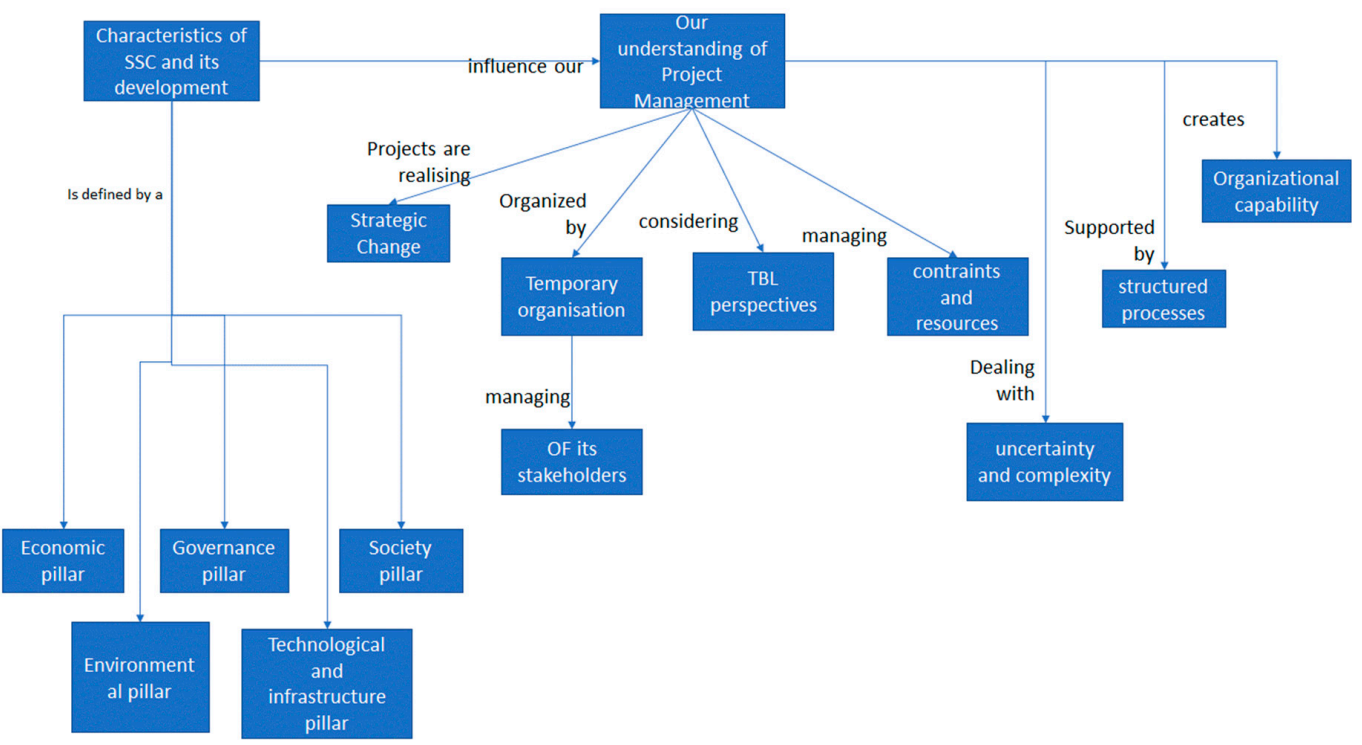

Figure 1. Initial concept map. 


\section{Findings}

This section describes the findings based on the research method described. We first present the results of a literature review on SSC development related to project management to derive guidelines for the interpretation of the conceptual mapping of the concepts of SSC and PM.

\subsection{Literature Review on SSC Development Related to Project Management}

Above, we have identified the main concepts of SSC and PM separately from the literature. While we are investigating the impact of SSC development on project management, we will also review the existing literature that specifically addresses these concepts. We have selected the existing literature by using Google Scholar and Researchgate with the key word "project management" combined with the terms "smart", "smart sustainable", and "city". This resulted in only one publication. While project management is also associated with other terminology, we repeated this search with all combinations of "smart", "sustainable", and "city" combined with the terms "implementation", "development", and "transformation". This resulted in 33 publications, which we reduced to eight after reading the abstract for their relevancy. For data extraction, we used several academic databases, such as Science Direct and ResearchGate to retrieve full publications for our analysis. Information from the articles was abstracted, and information was coded:

- Type of article

The publications were differentiated according their nature as either "conceptual" (deductive reasoning without empirical evidence) or "empirical" (supported by quantitative of qualitative data), or a "case study".

- Main contribution

Under this aspect, the publications were differentiated according to their focus on the development processes.

Our final sample of existing literature consists of eight articles published between 2012-2016. Remarkably, all of the publications related to the development of smart cities, thereby neglecting the explicit Smart Sustainable City development.

The development of cities can be seen as a transformation process from one city mode to another [12]. A multitude of city modes exist, which suggests various possible transformations, for example from a sanitary mode to a consumer or sustainable mode [12]. Due to the urban challenges, managing the urban environment into a sustainable mode stands out and has already been adopted by many cities around the world [12].

Table 5 shows the results of the structured literature review. Reviewing the contributions made by these publications $[87,88]$, it is shown that the role of the public and stakeholder dialogue in general stand out. As the authors of [89] state: "public participation is not only the most powerful driver, but also the most utilized factor to overcome the detected barriers".

Table 5. Publications on Smart (Sustainable) City implementation.

\begin{tabular}{cll}
\hline Reference & Type & \multicolumn{1}{c}{ Contribution } \\
\hline$[87]$ & Empirical & $\begin{array}{l}\text { Describes how the concept of the Smart City was the consequence of } \\
\text { information technology evolution. Also identifies six trends of Smart City } \\
\text { for government decision-makers and relevant researchers. }\end{array}$ \\
\hline [88] & Case & $\begin{array}{l}\text { As the Smart City movement is spontaneous, each city pursue its own goals } \\
\text { prioritizing smart initiatives of different nature. The paper studies two } \\
\text { Smart City best practices in Europe: Amsterdam and Genoa. }\end{array}$ \\
\hline
\end{tabular}


Table 5. Cont.

\begin{tabular}{|c|c|c|}
\hline Reference & Type & Contribution \\
\hline [32] & Case & $\begin{array}{l}\text { This paper sets out to investigate how a city, aspiring to become a } \\
\text { 'Smart City', can manage its internal organization to realize that ambition. } \\
\text { Specifically, it describes the case of the City of Ghent, Belgium, and the key } \\
\text { challenges it has been facing in its ongoing efforts to become a Smart City. }\end{array}$ \\
\hline [89] & Empirical & $\begin{array}{l}\text { This investigation has the aim of providing advice and support on the } \\
\text { implementation of smart city projects at the European Union level. } \\
\text { A quantitative feasibility study indicates a certain difficulty in carrying out } \\
\text { the investigated efforts. The following were identified as main barriers } \\
\text { (weaknesses and threats): (i.) subsidies, (ii.) communication between } \\
\text { project participants and the public, and (iii.) expertise in designing new } \\
\text { technologies and solutions. In contrast, the most effective drivers (strengths } \\
\text { and opportunities) are (i.) public participation, (ii.) cooperation between } \\
\text { different stakeholders, and (iii.) political commitment over the long term. }\end{array}$ \\
\hline [90] & $\begin{array}{l}\text { Conceptual with } \\
\text { case testing }\end{array}$ & $\begin{array}{l}\text { Within Smart City projects, the distinctions between design and use and } \\
\text { between government and citizen are blurring. Due to these blurring } \\
\text { boundaries, the roles of actors within Smart City projects change. The study } \\
\text { shows that the mutual shaping of roles and project dynamics can be } \\
\text { described by three separate dynamics. The first discusses the roles and } \\
\text { project dynamics related to the blurring boundaries between citizen and } \\
\text { government. The second is related to the blurring boundaries between } \\
\text { design and use. The last aspects are related to the project process. }\end{array}$ \\
\hline [91] & Case study & $\begin{array}{l}\text { Literature review reveals ICT and smart citizens as key elements of the } \\
\text { Smart City. Nevertheless, raising awareness of society is not a priority of } \\
\text { local municipalities, while trying to develop cities. A case study identifies } \\
\text { propositions on how the communication in the city could be improved. }\end{array}$ \\
\hline [92] & Conceptual & $\begin{array}{l}\text { Smart City (SC) transformation is a strategic process, which requires } \\
\text { novelty in approach, planning, operations, networking, and management } \\
\text { of urban enterprises. In this paper, we have proposed three strategic phases } \\
\text { of SC transformation process; (i) SC vision and status assessment, (ii) SC } \\
\text { transformational initiatives, and (iii) SC development and implementation. } \\
\text { To strategize the SC transformation scenario, this work attempts to identify } \\
\text { such factors for every phase of SC transformation on the basis of four } \\
\text { dimensional strategic elements and decision making matrix known as } \\
\text { Strengths-Weaknesses-Opportunities-Threats (SWOT) analysis. } \\
\text { Then, } 22 \text { factors of significant importance have been identified. Using AHP } \\
\text { and ANP methods, four alternative strategies are developed. Finally, } \\
\text { an integrative framework is proposed to strategize the alternatives for the } \\
\text { SC transformation process. }\end{array}$ \\
\hline
\end{tabular}

Empirical studies highlight the complexity and many challenges of the smart sustainable city development endeavor. Based on our review of the literature, we identified several types of challenges. The strategic misalignment addresses that many cities fail to see Smart City programs as part of their long-term, comprehensive development plan, and they do not engage in methodical strategic planning [21]. Although citizen engagement is seen as a primary success factor, the authors of $[44,89,93,94]$ noticed a frequent lack of communication to the city community. The authors of [90] is building on this; his research reveals that lines between the design and use and between government and citizen are blurring, which requires rethinking the roles of the actors who are involved. The authors of [9] mentioned various local situations such as social, governance, financial, and technological situations, which impose constraints and therefore challenges on the endeavor. Technological innovation runs at a much faster speed then specific infrastructure development, resulting in misaligning life cycle speeds [32]. Finally, political conviction [15], such as the statement that the "Smart City does not win you an election" [32] indicate that SSC topics are not always high on the political agenda. 
To support the development process, many corporations and city governments have proposed various frameworks. The authors of [9] concluded that each framework deals with the dimensions of a SSC in different ways, and each one has been designed to meet the needs and characteristics of the city to which it will be applied. Many of the frameworks support the development process by a phase-based approach, in which we can observe a commonality in the goals of these phases. For example, the identified frameworks agreed on the importance of the planning phase. The frameworks do not explicitly relate to projects and project management, although the phase-based approach of many frameworks imply at least an implicit link. An exception is [95], who refer to a key insight of transition theories: radical novelties may start in niches. Therefore, the sustainable urban projects that they refer to cannot be compared with the classical interpretation of an urban project at the housing block or district level, which is generally managed by a public authority. A customized approach is required.

The above insights serve as guidelines for our initial iteration, where we identify the characteristics of SSC development projects from the concepts derived.

\subsection{Initial Itertion: Characteristics of SSC Development Projects}

We have mapped the impact of the concepts of SSC onto the concepts of project management by viewing this as a matrix with 35 possible impacts. We have marked every logical impact and clustered entries in logical entities. This reveals four defining characteristics of SSC development projects (Table 6). We describe these below.

The drivers behind the development of the SSC show a global view in which objectives include economic growth, environmental health, and social vitality to ultimately improve the quality of life [16]. Therefore, these aspects are important aspects in the change, and its resulting deliverables and effects of these projects. From a scope perspective, it is clear that hardly any city, as seen from its administrative boundary, is self-sufficient. The city depends on the hinterland, which provides the city with resources and to which waste and pollutants from the city are taken. Therefore, the strategic scope for the development of a SSC is beyond the administrative boundary and should develop from the regional level up to the global and thereby societal scope $[12,96]$.

While data creation and technology are an important condition for SSC development, these projects are highly intensive with respect to these aspects. Deciding on the smart city architecture [97] and managing the business and IT alignment [32] are essential governance elements in the development of the SSC. The selected architecture should provide and maintain the project's viability in terms of its efficiency, extensibility, and interoperability. The continuous alignment of this architecture with business and city developments needs to be organized from the perspective of the project first, and the parental organizations deciding on the role of the (IT) departments [32].

The SSC is not always part of the city planning [21], and the city administration is often surprised by market interventions taking away the control function of the city administration. Unclear goals, visions, and missions add on to the differences among government, industry, and institutions [98], let alone the interests of urban dwellers and the hinterland representatives. Nevertheless, together they represent the city ecosystem [32], and therefore their connectivity is important.

This ambiguity regarding objectives $[16,18]$, mission, and vision can be explained by the involvement of many stakeholders with potentially conflicting interests in the development process. Sharp focused objectives, such as for example the development of a zero-carbon city, tend to narrow its scope and potentially prevent a truly sustainable city [30] from reaching the full quality of life for its citizens. While emerging strategies and bottom-up approaches also turn out to be valuable, we tend to pursue an agreed understanding among stakeholders on the level of detail regarding the SSC [99]. 
Table 6. Defining characteristics of SSC development projects.

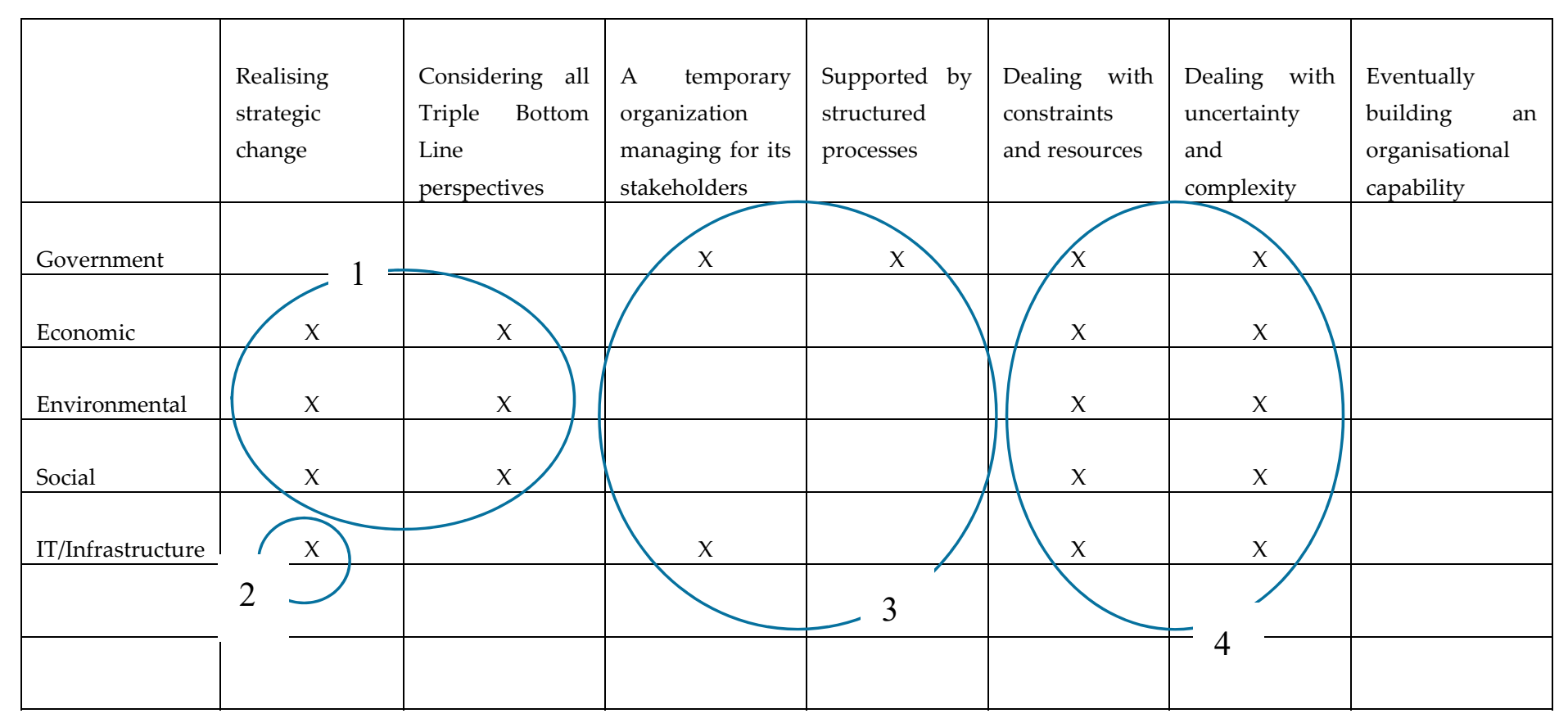

Legenda: 1. A global and multi-faceted view on change; 2. Highly data and technological intensive; 3 . SSC projects are autonomous managing for all stakeholders; 4 . Complex and project success defined beyond the iron triangle. 
Traditionally, projects have a (single) sponsor and a number of stakeholders to manage to keep them in the framework of predefined objectives and plans [66]. Due to the issues and variety of opinions, various authors mention the relevance of an integrated approach [15] and equivalent position for all stakeholders, ensuring that the SSC project remains a co-production between all of them [95] with a union of common interests [97] and win-win situations for all over time [32]. This requires a dedicated organization for promoting the Smart City [100]. This is a difficult and intensive process that is driven by tangible results and trust relationships [32]. Therefore, the project should show a healthy entrepreneurship in relative autonomy with access to meaningful alliances [95].

Although ICT is an important component of the SSC, it is only an enabler for its development, and the SSC must be based on the needs of the community [95]. A collaborative approach ensures that the project will benefit everyone and should address the full range of environment as well as livability, society, and prosperity topics [95]. Therefore, it is important to create interactive value-adding services engaging citizens in user-driven innovation [100] in the various city domains (e.g., smart mobility, smart education, smart healthcare, and smart safety). This requires open and accessible data that is available from all sources, including sensors, balanced with respect to privacy, and advanced intelligent technology, which supports the new value-added Smart City services [100].

Together with the setup of the project organization, it is the question of whether to explore and exploit city services top-down with a public funding approach or bottom-up, with a market-oriented approach. Cities may require a centralized and comprehensive approach to strike an appropriate balance between diverse service exploration in different domains and intensive service exploitation. The approach can vary over time, while market-oriented partnerships within a sustainable business model may contribute to growth at a more mature stage of the curve and a top-down, publicly-driven partnership may help to accelerate smart city adoption at an early stage. A city's choice will be determined by its embedded ICT-based industrial competitiveness and the dynamism of its likely public-private partnerships [100].

The SSC literature does not explicitly discuss when SSC projects are successful, although this is not beyond the level of SSC assessment frameworks. From the various SSC constraints [101] and additional stakeholders and components representing multiple (triple bottom line) perspectives, we generally expect that constraints, uncertainty, and complexity will increase. While managing constraints also implies criteria for success, we can reason that the criteria for stakeholder satisfaction, preparation for the future, and fit-for-purpose are the most important criteria for success. While SSC projects are frequently autonomous organisms with public and private funding, we can defend that the controlling and iron triangle criteria are relatively less important.

The project management processes support projects in order to create contextual, social, environmental and economic value [81]. Also, the authors of [100] argue that in order to drive the engagement among internal and external partners, it is necessary to apply a systemic management process to reach and realize a comprehensive SSC strategy. The processes should be part of the SSC roadmap identifying transformation activities and milestones [9], and should relate the SSC objectives and strategies to the supporting processes. Empirically, it is observed that many Smart City initiatives have an experimental nature, tend to be done in isolation, and do not reach a broad implementation phase [32].

\subsection{Second Iteration: Revising Our Understanding of Project Management}

The development of SSC addresses several societal issues regarding the people, public, and private organizations. With the clustering of people to the city area, we recognize the need to solve ecological, social, and economic challenges (and opportunities) for the majority of the people. Cities are more and more responsible to solve societal issues. By including the hinterland scope to the SSC scope, as we made plausible, we cover almost everything and everybody. It requires a sustainable approach to realize an improved quality of life for the current and future generations in the SSC context and beyond. More and more businesses and their customers will settle in the same urban area, thereby 
unifying several of their mutual interests. Therefore, we can say businesses and their projects take place in the context of the SSC. This is important, since we can then link PM to benefit the society and societal issues.

The characteristics of the projects and their management to develop the SSC also impose certain implications for our view on project management. Although the paradigm on the mainstream approach to PM has shifted already from a rational instrumental view to an instrument for change, surprisingly, this is hardly reflected in the definitions and major standards. For example, in discussing global (international) projects, the authors of [102] were amazed by the lack of any referral to the institutional theory. From Table 3, we can also see that, for example, stakeholder management isn't addressed at all, or it is limited to the "management of [the] stakeholders' view". This also holds for the aspect of constraints and criteria for project success.

From our study, we can redefine several parts of the PM concept map, which we will describe below. The corresponding concept map is shown in Figure 2

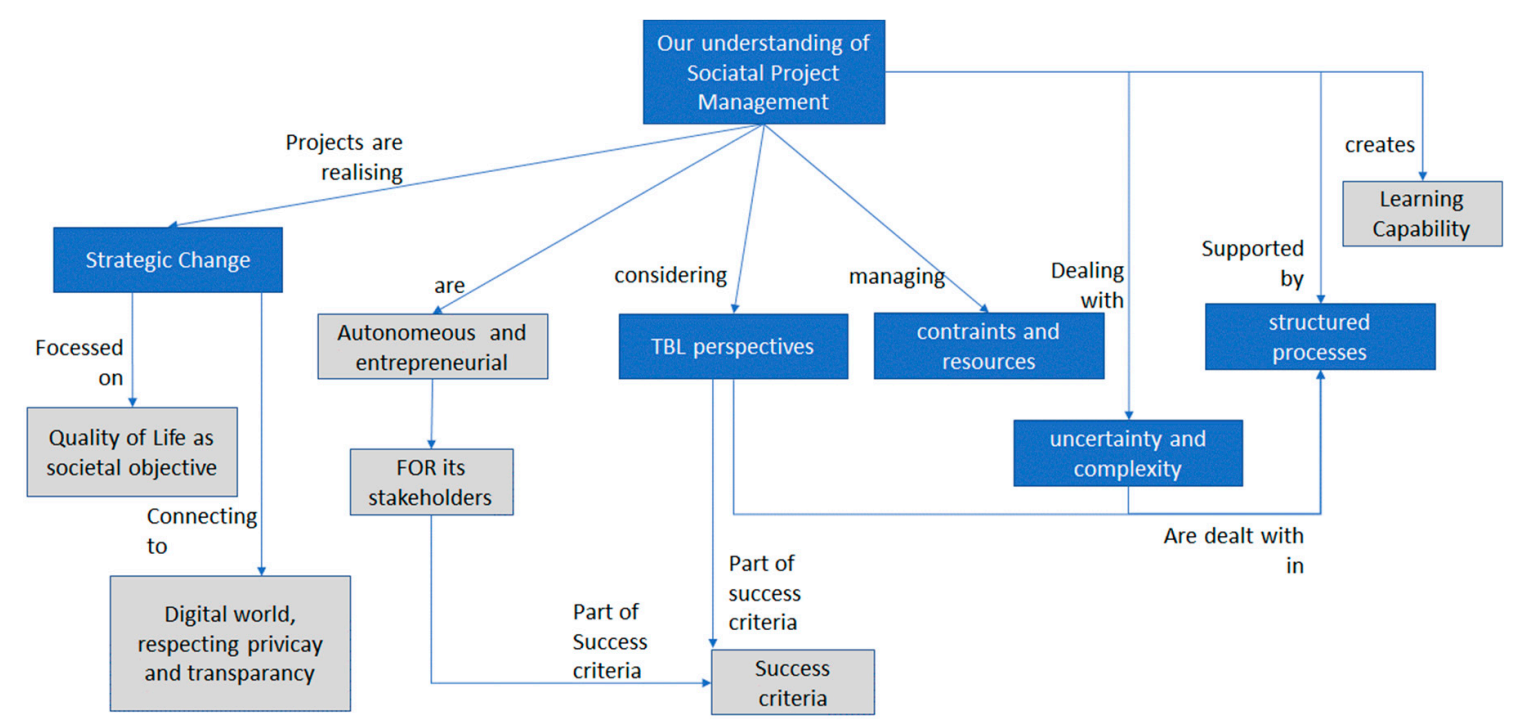

Figure 2. Revised concept map.

\subsubsection{Strategic Change Focused on Quality of Life as Societal Objective for PM}

The ultimate objective of the SSC is to improve the quality of life (QoL), which can be linked to $\mathrm{PM}$, and represents the societal purpose of the PM profession. From the definitions, characteristics, and objectives it is clear that economic (growth), environmental health, and social vitality are equally important and relevant to projects and their management [4].

The digitization of society is ubiquitously present in modern society and rapidly becoming indispensable. From the Smart (Sustainable) City architecture, we can learn that new value services to citizens (and customers) are realized by combining raw data from various sources. The new thinking is on (smart and privacy protective) data sharing instead of holding onto data, implicating that actively or passively connecting to the open data streams is relevant in building an enhanced society. Obviously, this requires a new perspective on transparency, privacy, and ethics.

\subsubsection{Autonomous Project Organizations with Different Success Criteria}

We see a development where projects become more and more temporary autonomous co-productions among various stakeholders, with an entrepreneurial approach. The latter will require projects to be (financially) self-reliant and not (solely) dependent of sponsor investments.

Also, with respect to project success criteria, we can define a new interpretation. We see a development to extend the classical iron triangle constraints and intend to control a predefined plan as 
a criteria for success by other more "mature" criteria of success: stakeholder satisfaction, preparation for the future, and fit for purpose. New criteria for success also have their implication for the supporting processes, which should support these criteria.

\section{Conclusions and Discussion}

\subsection{Originality and Impact}

The penetration of PM into every industry and function is called the "projectification of society" [1]. In this paper, we have discussed our assumption that societal changes should also influence the project management discipline. More specifically, we discussed the hypothesis that the evolvement of the project management discipline should be influenced by the developments in the SSC development context. We call the embracing of societal issues and transformation the "societalization" of PM. We have shown this influence by developing initial and revised concept maps.

Based on our analysis, we see the contours of a new definition for PM as follows:

"A collaborative endeavor of all affected stakeholders equivalently participating in exploring and exploiting, via an autonomous temporary organization, fit-for-purpose deliverables with connections to the digital platform, thereby aiming to prepare the entities of the affected stakeholders for the future regarding the economic, social and environmental aspects and ultimo improve the quality of life for all."

The integration of sustainable development concepts into the project management discipline is emerging. Nevertheless, this more specific approach is novel, which is apparent from the lack of existing literature on emerging SSC development concepts with the concepts of project management.

\subsection{Implications for PM Theory}

We can highlight several theoretical implications of our analysis, which we will describe below.

First, when we view the project from an institutional lens, the autonomous approach shifts the balance from an internal host organization orientation to the external societal orientation. Second, the cooperative and autonomous setup of projects limits the application of the agency theory to project management, while the principal agent relationship is deteriorating. This theory should be replaced by a stakeholder approach. To be precise, the stakeholder theory expands the classical and agency theory-related management "of" stakeholders into a managing "for" its stakeholders perspective. Thirdly, and in accordance with the above implications, we propose to more strongly position the complexity theory as a basis for project management. Complexity increases when taking a societal perspective, and its handling should be a foundational perspective on project management. Fourth, the increased data intensity and smartness imposes new questions on transparency, privacy, and ethical considerations.

\subsection{Implications for PM Practice}

We would like to highlight several practical implications of our analysis, which we will describe below. As a general rule, nothing can be done or achieved without resources such as finance, materials, and people [56]. However, an 'entrepreneural' project should be self-reliant in case of economic crisis of financial set back, and requires innovative business models beyond the traditional "investment" model to function adequately. This requires a need for a reasonable return on investment (ROI), especially for the private sector [103] in order to empower engagement [100].

With respect to people, it is obvious that [32] point to the presence of skilled workforce with a forward-thinking attitude that is motivated to adapt and drive change.

The project management processes support projects to create contextual, social, environmental, and economic value [81] and support the (selected) criteria for project success. Currently, the processes defined in the various bodies of knowledge [58,79] are primarily modeled to match the criteria of 
the iron triangle and control them. In contradiction, earlier we identified other criteria as being more important.

As discussed, a societal view increases the dynamic complexity as described by [77]. We built on the framework of [77] and argued for a dynamic management approach based on balancing control and interaction among stakeholders combined with "extraordinary efforts". They describe the extraordinary solutions as: a higher order of cooperation among stakeholders, project champions at the project level, competent people at the personal level, the capability of finding new management solutions, and using windows of opportunity. As we can see, this (dynamic management) approach is in line with the previously described interventions.

We consider embracing the triple bottom line not only in the project deliverable, but also in the process of project management as an additional element. We would like to mention the 13 impact areas developed by [6] to integrate sustainability into the project management and delivery processes. Following [104], project sustainability strategies can be formulated by the project host organizations and the project themselves.

The innovative characterization of projects requires the processes to also provide a guiding approach uniting planned and emerging experimentation, learning, and broad-scale implementation.

It can also be expected that autonomous temporary organizations and their supplying host organizations can benefit from a "capability improvement" perspective. We would argue that a new PM framework would include a learn and repeat phase to describe recurring projects, events, and processes for integration. The aim of this phase is to improve outcomes and service delivery as a result of repeatable processes for projects.

\subsection{Implications to Public Policy on SSC Development}

We have characterized SSC development as (multiple coherent) projects. Nevertheless, our literature review regarding this topic hardly showed evidence of a systematic project-based approach. Several earlier identified restrictions of SSC development could benefit from the project management concepts we identified. The often-missed aspect of citizen engagement would be logically included when an SSC development project is seen as a strategic change for all of its stakeholders, including (or especially) citizens. Adopting the triple bottom line perspectives and new revised criteria for project success would also fit the public nature of SSC projects. Also, the supporting frameworks for SSC development do not cover elements from the PM discipline. Subsequently these would benefit from our concepts for PM in order to further structure the development process.

\subsection{Limitations of the Research}

This research is limited by being mainly conceptual and interpretative with little empirical backup.

\subsection{Future Research}

Our study is interpretive in nature, so a recommended direction for further research would be the empirical testing of the proposed revised concepts of societal project management in general, and for SSC development projects specifically. Also, further exploration of PM standards reflecting our above analysis would be one of the next steps. These standards would reflect updated insights for supporting processes. Another relevant research topic would be research on new project governance structures, while the founding principal-agent theory is deteriorating upon the outlined developments.

Author Contributions: Conceptualisation, Writing-Original Draft Preparation, R.P.J.R.S. Writing-Review \& Editing, A.J.G.S.

Funding: This research received no external funding.

Conflicts of Interest: The authors declare no conflict of interest. 


\section{References}

1. Bierwolf, R.; Romero, D.; Pelk, H.; Stettina, C.J. On the Future of Project Management Innovation. In Proceedings of the 2017 International Conference on Engineering, Technology and Innovation (ICE/ITMC), Funchal, Portugal, 27-29 June 2017.

2. Silvius, A.J.G.; Schipper, R.P.J.; Van Den Brink, J.; Planko, J. Sustainability in Project Management; Gower Publishing, Ltd.: Aldershot, UK, 2012.

3. World Commission on Environment and Development. Our Common, Future; Oxford University Press: Oxford, UK, 1987.

4. Silvius, G. Sustainability as a new school of thought in project management. J. Clean. Prod. 2017, 166, 1479-1493. [CrossRef]

5. International Project Management Association. Individual Competence Baseline for Project, Programme $\mathcal{E}$ Portfolio Management, 4th ed.; International Project Management Association: Nijkerk, The Netherlands, 2015.

6. Silvius, A.J.; Schipper, R.P. Sustainability in project management: A literature review and impact analysis. Soc. Bus. 2014, 4, 63-96. [CrossRef]

7. Al-Nasrawi, S.; Adams, C.; El-Zaart, A. A conceptual multidimensional model for assessing smart sustainable cities. J. Inf. Syst. Technol. Manag. 2015, 12, 541-558.

8. Chourabi, H.; Nam, T.; Walker, S.; Gil-Garcia, J.R.; Mellouli, S.; Nahon, K.; Pardo, T.A.; Scholl, H.J. Understanding smart cities: An integrative framework. In Proceedings of the 2012 45th Hawaii International Conference on System Science (HICSS), Maui, HI, USA, 4-7 January 2012; pp. 2289-2297.

9. Ibrahim, M.; Adams, C.; El-Zaart, A. Paving the way to smart sustainable cities: Transformation models and challenges. JISTEM-J. Inf. Syst. Technol. Manag. 2015, 12, 559-576. [CrossRef]

10. Gareis, R. Changes of organizations by projects. Int. J. Proj. Manag. 2010, 28, 314-327. [CrossRef]

11. Olsen, R.P. Can project management be defined? Proj. Manag. Q. 1971, 2, 12-14.

12. Pickett, S.T.A.; Boone, C.G.; McGrath, B.P.; Cadenasso, M.L.; Childers, D.L.; Ogden, L.A.; McHale, M.; Grove, J.M. Ecological science and transformation to the sustainable city. Cities 2013, 32, S10-S20. [CrossRef]

13. Hara, M.; Nagao, T.; Hannoe, S.; Nakamura, J. New key performance indicators for a smart sustainable city. Sustainability 2016, 8, 206. [CrossRef]

14. United Nations, Department of Economic and Social Affairs, Population Division. Concise Report on the World Population Situation in 2014. Available online: http://www.un.org/en/development/desa/ population/publications/trends/concise-report2014.shtml (accessed on 1 May 2018).

15. Ramamurthy, A.; Devadas, M.D. Smart Sustainable Cities: AN Integrated Planning Approach towards Sustainable Urban Energy Systems, India. Available online: https:/ / www.researchgate.net/publication/ 264464713_Smart_Sustainable_Cities_An_Integrated_Planning_Approach_towards_Sustainable_Urban_ Energy_Systems_India (accessed on 25 May 2018).

16. Dameri, R.P.; Cocchia, A. Smart city and digital city: Twenty years of terminology evolution. In Proceedings of the X Conference of the Italian Chapter of AIS, Milano, Italy, 14 December 2013; pp. 1-8.

17. Hens, L. The challenge of the sustainable city. Environ. Dev. Sustain. 2010, 12, 875-876. [CrossRef]

18. Höjer, M.; Wangel, J. Smart sustainable cities: Definition and challenges. In ICT Innovations for Sustainability; Springer: Cham, Switzerland, 2015; pp. 333-349.

19. Arroub, A.; Zahi, B.; Sabir, E.; Sadik, M. A literature review on Smart Cities: Paradigms, opportunities and open problems. In Proceedings of the 2016 International Conference on Wireless Networks and Mobile Communications (WINCOM), Fez, Morocco, 26-29 October 2016; pp. 180-186.

20. Bibri, S.E.; Krogstie, J. Smart sustainable cities of the future: An extensive interdisciplinary literature review. Sustain. Cities Soc. 2017, 31, 183-212. [CrossRef]

21. Angelidou, M. Smart cities: A conjuncture of four forces. Cities 2015, 47, 95-106. [CrossRef]

22. Mosannenzadeh, F; Vettorato, D. Defining smart city. A conceptual framework based on keyword analysis. TeMA J. Land Use Mobil. Environ. 2014. [CrossRef]

23. Albino, V.; Berardi, U.; Dangelico, R.M. Smart cities: Definitions, dimensions, performance, and initiatives. J. Urban Technol. 2015, 22, 3-21. [CrossRef]

24. Caragliu, A.; Del Bo, C.; Nijkamp, P. Smart cities in Europe. J. Urban Technol. 2011, 18, 65-82. [CrossRef] 
25. Nam, T.; Pardo, T.A. Conceptualizing smart city with dimensions of technology, people, and institutions. In Proceedings of the 12th Annual International Digital Government Research Conference: Digital Government Innovation in Challenging Times, College Park, MD, USA, 12-15 June 2011; pp. 282-291.

26. Giffinger, R.; Gudrun, H. Smart cities ranking: An effective instrument for the positioning of the cities? ACE Archit. City Environ. 2010, 4, 7-26.

27. Anavitarte, L.; Tratz-Ryan, B. Market Insight: 'Smart Cities' in Emerging Markets; Gartner: Stamford, CT, USA, 2010. Available online: http:/ / www.gartner.com/id=1468734 (accessed on 1 May 2018).

28. IDA Singapore. iN2015 Masterplan. 2012. Available online: http://www.ida.gov.sg/ /media/Files/ Infocomm\%20Landscape/iN2015/Reports/realisingthevisionin2015.pdf (accessed on 1 May 2018).

29. Lombardi, S.; Giordano, H.F.; Yousef, W. Modelling the Smart City Performance. Innov. Eur. J. Soc. Sci. Res. 2012, 25, 137-149. [CrossRef]

30. Hassan, A.M.; Lee, H. The paradox of the sustainable city: Definitions and examples. Environ. Dev. Sustain. 2015, 17, 1267-1285. [CrossRef]

31. Duxbury, N.; Cullen, C.; Pascual, J. Cities, culture and sustainable development. Cultural policy and governance in a new metropolitan age. Cult. Glob. Ser. 2012, 5, 73-86.

32. Kramers, A.; Höjer, M.; Wangel, J. Planning for smart sustainable cities: Decisions in the planning process and actor networks. In Proceedings of the 2nd International Conference on ICT for Sustainability (ICTS), Stockholm, Sweden, 24-27 August 2014; pp. 299-305.

33. Hill, D. Smarts and the City. Waste Manag. Environ. 2010, 21, 20.

34. Remaco, S.A. Jessica-Joint European Support for Sustainable Investment in City Areas; Jessica Instruments for Energy Efficiency in Greece-Evaluation Study, Final Report; European Commission: Brussels, Belgium, 2010.

35. Cohen, B. What Exactly Is A Smart City? 2012. Available online: http://www.fastcoexist.com/1680538/ what-exactly-is-a-smart-city (accessed on 25 May 2018).

36. Hitachi. Smart City Overview. Smart Cities: Hitachi. Available online: http://www.hitachi.com/products / smartcity/vision/concept/overview.html (accessed on 9 February 2014).

37. Hwang, J.S.; Young, O.G.; Choe, H. Smart Cities Seoul: A Case Study; ITU-T Technology Watch Report; ITU: Geneva, Switzerland, February 2013.

38. EP. Mapping Smart Cities in the EU; European Union (EU), European Parliament's Committee on Industry, Research and Energy, Policy Department A: Economic and Scientific Policy: Brussels, Belgium, 2014.

39. BSI. Smart Cities_Vocabulary; BSI Standards Publication, PAS 180:2014; British Standards Institute (BSI): London, UK, 2014.

40. International Telecommunications Union (ITU). Technical Specifications on "Setting the Framework for an ICT Architecture of a Smart Sustainable City" (SSC-0345). 2015. Available online: http:/ /www.itu.int/en/ ITUT/focusgroups/ssc/Pages/default.aspx (accessed on 1 May 2018).

41. Wiig, A. IBM's smart city as techno-utopian policy mobility. City 2015, 19, 258-273. [CrossRef]

42. Joshi, S.; Saxena, S.; Godbole, T. Developing smart cities: An integrated framework. Procedia Comput. Sci. 2016, 93, 902-909. [CrossRef]

43. ITU. An Overview of Smart Sustainable Cities and the Role of Information and Communication Technologies; ITU-T Focus Group on Smart Sustainable Cities: Geneva, Switzerland, 2014.

44. Dameri, R.P.; Rosenthal-Sabroux, C. Smart city and value creation. In Smart City; Springer International Publishing: Cham, Switzerland, 2014; pp. 1-12.

45. Marcelino-Sádaba, S.; Pérez-Ezcurdia, A.; González-Jaen, L.F. Using ProjectManagement as a way to sustainability. From a comprehensive review to a framework definition. J. Clean. Prod. 2015, 99, 1-16. [CrossRef]

46. Turner, J. Towards a theory of project management: The nature of the project. Int. J. Proj. Manag. 2006, 24, 1-3. [CrossRef]

47. Weick, K.E. The Social Psychology of Sensemaking; Random House: New York, NY, USA, 1979.

48. Turner, J.R. Editorial: International Project Management Association global qualification, certification and accreditation. Int. J. Proj. Manag. 1996, 14, 1-6. [CrossRef]

49. Turner, J.R. What are Projects and Project Management; Henley Working Paper 9002; Henley Management College: Henley-on-Thames, UK, 1990. 
50. Turner, J.R.; Müller, R. On the nature of the project as a temporary organization. Int. J. Proj. Manag. 2003, 21, 1-8. [CrossRef]

51. Declerck, R.; Debourse, J.; Declerck, J. Le Management Stratégique: Contrôle de L'Irréversibilité; Les éditions ESC Lille: Lille, France, 1997.

52. Saravanan, K.; Hrishikesh, M.P. Project Planning Excerpts from Tamil Classical Literature Thirukkural. Int. J. Emerg. Res. Manag. Technol. 2013, 2, 69-74.

53. Munns, A.K.; Bjeirmi, B.F. The role of project management in achieving project success. Int. J. Proj. Manag. 1996, 14, 81-87. [CrossRef]

54. PMI. A Guide to the Project Management Body of Knowledge, 4th ed.; Project Management Institute: Newtown Square, PA, USA, 2000.

55. Cleland and Ireland. Project Management: Strategic Design and Implementation, 4th ed.; McGraw Hill: New York, NY, USA, 2002; Volume 1.

56. Kerzner, H. Project Management: A Systems Approach to Planning, Scheduling, and Controlling; John Wiley \& Sons: Upper Saddle River, NJ, USA, 2013.

57. Larson, E.W.; Gray, C.F. Project Management the Managerial Process, 5th ed.; McGraw-Hill/Irwin: New York, NY, USA, 2011.

58. Project Management Institute. A Guide to Project Management Body of Knowledge (PMBOK ${ }^{\circledR}$ Guide), 5th ed.; Project Management Institute: Newtown Square, PA, USA, 2013.

59. Adelina-Roxana, G.; Alice-Magdalena, S. Project Management Considered In a 2014 Perspective. Ann.-Econ. Ser. 2014, 2014, 412-417.

60. Van den Bergh, J.; Viaene, S. Unveiling smart city implementation challenges: The case of Ghent. Inf. Polity 2016, 21, 5-19. [CrossRef]

61. Atkinson, R. Project management: Cost, time and quality, two best guesses and a phenomenon, its time to accept other success criteria. Int. J. Proj. Manag. 1999, 17, 337-342. [CrossRef]

62. Weiss, J.P. Organizational Behavior and Change Managing Diversity, CrossCultural Dynamics, and Ethics, 2nd ed.; South Western College Publishing: Cincinnati, OH, USA, 2001.

63. Eskerod, P.; Huemann, M.; Savage, G. Project stakeholder management: Past and present. Proj. Manag. J. 2015, 46, 6-14. [CrossRef]

64. Leybourne, S.A. The changing bias of project management research: A consideration of the literatures and an application of extant theory. Proj. Manag. Q. 2007, 38, 61. [CrossRef]

65. Freeman, R.E. Strategic Management: A Stakeholder Approach; Pitman/Ballinger: Boston, MA, USA, 1984.

66. Eskerod, P.; Huemann, M. Sustainable development and project stakeholder management: What standards say. Int. J. Manag. Proj. Bus. 2013, 6, 36-50. [CrossRef]

67. Eskerod, P.; Huemann, M. Managing for stakeholders. In Gower Handbook of Project Management, 5th ed.; Turner, J.R., Ed.; Gower: Farnham, UK, 2014.

68. Freeman, R.E.; Harrison, J.S.; Wicks, A.C. Managing for Stakeholders: Survival, Reputation, and Success; Yale University Press: New Haven, CT, USA, 2007.

69. Freeman, R.E.; Harrison, J.S.; Wicks, A.C.; Parmar, B.L.; de Colle, S. Stakeholder Theory: The State of the Art; Cambridge University Press: Cambridge, UK, 2010.

70. Labuschagne, C.; Brent, A.C. Sustainable project life cycle management: The need to integrate life cycles in the manufacturing sector. Int. J. Proj. Manag. 2015, 23, 159-168. [CrossRef]

71. Eid, M. Sustainable Development \& Project Management; Lambert Academic Publishing: Cologne, Germany, 2009.

72. Maltzman, R.; Shirley, D. Green Project Management; CRC Press: Boca Raton, FL, USA, 2011.

73. Hannan, M.T.; Freeman, J. Organizational Ecology; Harvard University Press: Cambridge, MA, USA, 1993.

74. BSR/GlobeScan. State of Sustainable Business Poll. 2012. Available online: http:/ /www.globescan.com/ component/edocman/?task=document.viewdoc\&id=43\&Itemid=591 (accessed on 8 January 2013).

75. Görög, M. A broader approach to organisational project management maturity assessment. Int. J. Proj. Manag. 2016, 34, 1658-1669. [CrossRef]

76. Silvius, A.G.; Schipper, R. Exploring the relationship between sustainability and project success-conceptual model and expected relationships. SciKA-Assoc. Promot. Dissem. Sci. Knowl. 2016, 4, 5-22.

77. Hertogh, M.; Westerveld, E. Playing with Complexity. Management and Organisation of Large Infrastructure Projects; Erasmus University Rotterdam: Rotterdam, The Netherlands, 2010. 
78. Pich, M.T.; Loch, C.H.; Meyer, A.D. On uncertainty, ambiguity, and complexity in project management. Manag. Sci. 2002, 48, 1008-1023. [CrossRef]

79. International Organization for Standardization. ISO 21505:2017, Project, Programme and Portfolio Management_Guidance on Governance; ISO: Geneva, Switzerland, 2017.

80. Shenhar, A.J.; Dvir, D. Project management research-the challenge and opportunity. Proj. Manag. J. 2007, 38, 93. [CrossRef]

81. Winter, M.; Smith, C.; Morris, P.; Cicmil, S. Directions for future research in project management: The main findings of a UK government-funded research network. Int. J. Proj. Manag. 2006, 24, 638-649. [CrossRef]

82. Davies, A.; Hobday, M. The Business of Projects: Managing Innovation in Complex Products and Systems; Cambridge University Press: Cambridge, UK, 2005.

83. Ausubel, D.P.; Novak, J.D.; Hanesian, H. Educational Psychology: A Cognitive View, 2nd ed.; Holt, Rinehart and Winston: New York, NY, USA, 1978.

84. Novak, J.D.; Cañas, A.J. The Theory Underlying Concept Maps and How to Construct and Use Them; Technical Report IHMC CmapTools 2006-01; Institute for Human and Machine Cognition: Pensacola, FL, USA, 2008.

85. Novak, J.D.; Gowin, D.B. Learning How to Learn; Cambridge University Press: New York, NY, USA, 1984.

86. Cañas, A.J.; Novak, J.D.; Reiska, P. How good is my concept map? Am I a good Cmapper? Knowl. Manag. E-Learn. Int. J. 2015, 7, 6-19.

87. Hao, L.; Lei, X.; Yan, Z.; Yang, C.L. The application and Implementation research of Smart City in China. In Proceedings of the 2012 International Conference on System Science and Engineering (ICSSE), Dalian, China, 30 June-2 July 2012; pp. 288-292.

88. Dameri, R.P. Smart City and Digital City Implementation: Two Best Practices in Europe. In Smart City Implementation; Springer International Publishing: New York, NY, USA, 2017; pp. 109-154.

89. Pezzutto, S.; Fazeli, R.; De Felice, M. Smart City Projects Implementation in Europe: Assessment of Barriers and Drivers. Int. J. Contemp. Energy 2016, 2. [CrossRef]

90. Nijman, H. Dynamic Roles in Smart City Development. Master's Thesis, University of Twente, Enschede, The Netherlands, 2014.

91. Šiuryte, A. An Analysis of Key Factors in Developing a Smart City. Ph.D. Thesis, Mykolas Romeris University, Vilnius, Lithuania, 2016.

92. Halepoto, I.; Sahito, A.A.; Shoro, G.M. Design of Integrated Analytical Process Framework for Smart City Transformation based on Strengths-Weaknesses-Opportunities-Threats Analysis. Sindh Univ. Res. J. (Sci. Ser.) 2015, 47, 221-230.

93. Dameri, R.P.; Negre, E.; Rosenthal-Sabroux, C. Triple Helix in Smart cities: A literature review about the vision of public bodies, universities, and private companies. In Proceedings of the 2016 49th Hawaii International Conference on System Sciences (HICSS), Koloa, HI, USA, 5-8 January 2016; pp. 2974-2982.

94. Kogan, N.; Lee, K.J. Exploratory research on success factors and challenges of Smart City Projects. Asia Pac. J. Inf. Syst. 2014, 24, 141-189. [CrossRef]

95. Devolder, S.; Block, T. Transition thinking incorporated: Towards a new discussion framework on sustainable urban projects. Sustainability 2015, 7, 3269-3289. [CrossRef]

96. Egger, S. Determining a sustainable city model. Environ. Model. Softw. 2006, 21, 1235-1246. [CrossRef]

97. Anthopoulos, L. Defining smart city architecture for sustainability. In Proceedings of the 14th IFIP Electronic Government (EGOV) and 7th Electronic Participation (ePart) Conference 2015, Thessaloniki, Greece, 30 August-3 September 2015; IOS Press: Amsterdam, The Netherlands, 2015; pp. 140-147.

98. Kitchin, R. Making sense of smart cities: Addressing present shortcomings. Camb. J. Reg. Econ. Soc. 2015, 8, 131-136. [CrossRef]

99. Adnan, Y.M.; Hamzah, H.; Dali, M.M.; Daud, M.N.; Alias, A. An initiatives-based framework for assessing smart city. Plan. Malays. J. 2016. [CrossRef]

100. Lee, J.H.; Hancock, M.G.; Hu, M.C. Towards an effective framework for building smart cities: Lessons from Seoul and San Francisco. Technol. Forecast. Soc. Chang. 2014, 89, 80-99. [CrossRef]

101. De Wijs, L.; Witte, P.; Geertman, S. How smart is smart? Theoretical and empirical considerations on implementing smart city objectives-A case study of Dutch railway station areas. Innov. Eur. J. Soc. Sci. Res. 2016, 29, 424-441. [CrossRef] 
102. Battistuzzo, F.J.; Piscopo, M. Global projects: A bibliometric study of international business journals. Apresentação 2015, 10, 31-45.

103. Kondepudi, S. A Step by Step Approach towards Planning a Smart Sustainable City Using a Strategic Plan; Special Issue; Elk Asia Pacific Journals: Delhi, India, 2015; ISBN 978-81-930411-5.

104. Aarseth, W.; Ahola, T.; Aaltonen, K.; Økland, A.; Andersen, B. Project sustainability strategies: A systematic literature review. Int. J. Proj. Manag. 2017, 35, 1071-1083. [CrossRef]

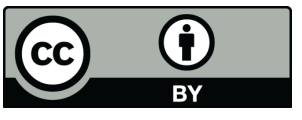

(c) 2018 by the authors. Licensee MDPI, Basel, Switzerland. This article is an open access article distributed under the terms and conditions of the Creative Commons Attribution (CC BY) license (http:/ / creativecommons.org/licenses/by/4.0/). 